\title{
Safeguarding Marine Biodiversity in a Changing World: Maltese Small-Scale Fisheries and Alien Species
}

\author{
Adriana Vella and Noel Vella \\ Additional information is available at the end of the chapter \\ http://dx.doi.org/10.5772/intechopen.76609
}

\begin{abstract}
Right in the center of the Mediterranean Sea, the Maltese Islands are well situated for monitoring regional marine biodiversity changes. Among the latter are the increasing alien species coming in through the Suez Channel and the Straits of Gibraltar or brought in through various anthropogenic vectors. The non-native species that turn into invasive do not only affect native marine communities but also the aging and shrinking Maltese small-scale fisheries (SSF) community. SSF are predicted to go extinct and with them their well-known colorful artisanal fishing boats with the eyes of Osiris, which were thought to protect them. In the meantime, large-scale fishing activities have been growing through EU and national legislations, promoting profits over long-term conservation of natural resources and cultural heritage of small fishing communities. This chapter considers the relevance of a changing marine environment and the challenges ahead to safeguard Mediterranean biodiversity, which provides its goods and services to man. The role of well-managed sustainable small-scale fisheries in overcoming some of these challenges is considered.
\end{abstract}

Keywords: Maltese small-scale fisheries, alien species, biodiversity, heritage, conservation, Mediterranean Sea

\section{Introduction}

The Mediterranean fisheries sector benefits from sustainable and traditional artisanal small-scale fisheries (SSF) practices, with fishers usually spending all their lives and efforts harvesting goods that the sea provides in a manner that would allow them and their children to continue to do so, generation after generation. Through the centuries, the art of artisanal fishing and SSF developed a unique national cultural heritage linking ways of 
making a living from the sea with traditional vessel designs, small-scale economies, culinary and religious practices at the heart of each fishing village and community [1]. Different Mediterranean countries have developed various fishing techniques and exploitation rates often in line with the demands for specific consumption preferences by their populations [2]. Sustainable use of marine resources needs to consider the diversity of each country's consumption demands on local marine resources and the additional demands for export toward foreign countries, while assessing the influence of these on marine biodiversity. The former often playing an important role in causing over-exploitation, while increasing the ecological footprint of the fishery industry in the Mediterranean [3].

By focusing on Malta's artisanal fisheries and marine biodiversity changes, the future of sustainable SSF in such changing environment may be considered through the experiences of one of the smallest SSF communities in the EU situated right at the heart of the Mediterranean Sea. The 25 NM Fisheries Management Zone (FMZ) around the Maltese islands is also a unique opportunity to test the efficacy of fisheries and conservation research to improve management, hand in hand with the consideration of stakeholder livelihoods and poverty alleviation while protecting marine biodiversity, ecosystems and Maltese artisanal fisheries and heritage.

In the Mediterranean, where not all states are under EU management regulations, the shared exploitation of resources is not easy and may also depend on the General Fisheries Commission for the Mediterranean (GFCM) to guide and monitor fisheries management more holistically. Apart from the growing need to assess the actual consumption and demand on marine resources by both Mediterranean and non-Mediterranean countries, updated analyses of the actual status of marine resources continues to lag behind $[3,4]$. One example is the varying degree of accuracy in fish landings statistics, which depend on correct identification of every species landed and affected by the fishing activity. Long-term and accurate data are crucial for any realistic assessment of Mediterranean fisheries resources and management. In the absence of reliable data and stock assessments, sensible management decisions remain an unreachable goal. Another important gap in knowledge is the data on discards, which rarely get to be recorded. Fisheries discards highly vary along the region both geographically and among the different fishing gears [5]. Such discards data are very important not only to evaluate potential adaptations and improvements in the fisheries but also as monitoring data on the changing communities of marine species present and affected by the fisheries activities in this semi-enclosed sea. This is becoming even more valuable in the light of increasing presence of non-native or alien species, the impacts of which urgently need to be accurately monitored and evaluated across the Mediterranean [6-9].

Though essential data are incomplete and at times imprecise, there is an increasing strive to continue expanding the ways in which Mediterranean marine resources may be exploited through the latest Blue Growth proposals for this region. Different directives including the Integrated Maritime Policy (IMP) adopted in 2007; the Marine Strategy Framework Directive (MSFD), the environmental pillar of the IMP adopted in 2008 and the Marine Spatial Planning Directive (MSPD) adopted in 2014, all aiming toward improving knowledge, monitoring and management for long-lasting benefits from the goods and services the marine environment provide [10, 11]. As new maritime sectors such as, seabed mining and biotechnology are expected to develop, concerns on possible impacts on both the marine ecosystems and traditional sectors increase [12]. 
With so many developments expected in this already overexploited Mediterranean Sea, the role of traditional artisanal fishing in conserving local maritime heritage may be replaced in the near future, unless integrated planning and management will involve small-scale fishers. SSF and small coastal communities, play a fundamental role in the social identity and heritage of the Mediterranean. Artisanal fishermen depend directly on the marine natural resources for their income [13]. The EU's small-scale fishing sector comprises around 70,000 vessels and amounts to $84 \%$ of the EU fishing fleet and $54 \%$ of the total EU fleet effort (in days at sea). Although it only covers $11 \%$ of the EU fleet's gross tonnage, it contributes to $48 \%$ of employment in EU fisheries, with approximately 72,800 fishers (this figure increases if we include "informal employment", that is the spouses, partners and other family members who assist the primary earner). Around $55 \%$ of it is concentrated in the Mediterranean basin (EU info 2016 small-scale coastal fleet).

Right at the center of the Mediterranean Sea, Maltese fishermen face competition with many other fishermen exploiting marine resources in the same national and international waters. In accordance with the Act of Accession, Council Regulation (EC) No 813/2004, the 25 NM FMZ around Malta was established with provisions outlined in Article 26 of Council Regulation $1967 / 2006$. In view of this, the fisheries covered by this management plan follow measures limiting fishing effort, capacity, vessel size, engine power and fishing areas for certain modes of fishing. The Maltese fishing fleet is predominantly small-scale with a diverse selection of artisanal fishing techniques and seasonal shifts in the target species, allowing for sustainable fishing niches, which usually allow affected species to recover while exploitation is shifted to other species. Malta adopts SSF as per definition found in Article 26 of Council Regulation No 1198/2006 and in the new European Maritime and Fisheries Fund where Small-scale fishing involves "vessels less than 12 metres and not using towed gear" as listed in table 3 in Annex 1 of Commission Regulation (EC) No 26/2004 of December 2003 [14]. However, a number of fishing activities conducted by vessels larger than $12 \mathrm{~m}$ are allowed within the $25 \mathrm{NM}$ FMZ by way of derogation. These include a limited number of trawlers, vessels fishing for dolphinfish (Coryphaena hippurus), vessels fishing with small pelagic purse seines and long-liners [15].

Maltese landings accounts for around $0.03 \%$ of the total EU catch; The Scientific, Technical and Economic Committee for Fisheries [16-19] notes that due to the larger neighboring countries' fisheries effort, the current status of stocks in the Mediterranean depends little on the activity of the Maltese fishing fleet. These points toward the need for careful consideration of the distinctions between different Mediterranean fishing fleet sizes, scales, and sustainability. At the same time, coordination of the different well adapted regulations across the Mediterranean have to be in place to encourage fishers in this region to participate in safeguarding marine biodiversity in effective ways. This would facilitate the SSF in Mediterranean find ways to apply Article 19 of Council Regulation 1967/2006 [14, 15]. This SSF sector in Malta is governed by regional and national legislations and regulations that have focused around the type of gear allowed, minimum landing sizes of fishes, closed seasons and area restrictions [EC Regulations: 1967/2006; 1343/2011; 302/2009; Local regulations CAP 425-Fisheries Conservation and Management Act and its various subsidiary legislations and amendments, including fishing vessel regulations Legal Notice 407] [14, 20].

With increasing recreational fishing vessels in Malta, falling under practically no fishing monitoring process, the illegal, unregulated and unreported (IUU) fishing problem may be 
exacerbated many-fold. At the same time if regulated, recreational fishing could involve a monitoring protocol to watch for alien species around Maltese coasts. According to the Data Collection Framework Regulation (2008/949/EC): for non-recreational fishing vessels less than $10 \mathrm{~m}$ in length, data on catch and effort is collected through a Catch Assessment Survey (CAS); whereas, for vessels over $10 \mathrm{~m}$, data is collected through logbooks. Such data collection could therefore provide valuable information on alien species in fishing areas as well.

According to the aggregated data on small-scale fishing vessels from the Department of Fisheries-Fishing Vessel Register of Malta, in 2015, 2887 SSF vessels (96.8\%) were below the $12 \mathrm{~m}$ length, with 335 vessels (13.5\%) used by full-time fishermen and 599 vessels $(20.1 \%)$ used by part-time fishermen. The much larger number of vessels under $12 \mathrm{~m}$ registered for recreational fishermen amounts to 1942 (65.1\%) of the total fishing fleet. With so many fishing boats, it would be useful to rope in efforts to monitor against the changing, deteriorating, and impoverishing resources. Greater collaboration among fishermen, researchers and policy-makers is essential toward effective measures for good marine environmental status and biodiversity conservation.

The cultural and environmental heritage of the small Maltese fishing industry far outweighs its negligible economic contribution. The fishermen's livelihoods depend on the sale of highly prized species that are made available to the consumer as fresh fish caught by traditional artisanal methods during very short fishing trips. The variety and quality of the catch also contributes significantly to the economically important tourism industry. Fishing villages and fish restaurants are a significant attraction for tourists. Maltese traditional fishing boats, such as the "Kajjik" (922 boats) and "Luzzu" (275 boats) are wooden boats operating mostly in coastal waters. However, the more popular multipurpose vessels (1346 boats) operate at variable distances from the coast. The colorful traditional fishing boats with the eyes of Osiris (Figure 1), thought to protect the fishermen, are a tourist favorite. Seasonality in the activity, gears used and landings provide interesting diversity to tourists visiting at different times of the year [21]. This being a valuable asset when efforts to spread tourism throughout the year is a priority for the small Maltese islands. Cultural heritage is also promoted in fishing villages through sculptures that recall traditional activities (Figure 2).

Through the years however, many Maltese fisher families have seen their sons and daughters look elsewhere for their future careers, abandoning the idea of undertaking fishing as a fulltime or part-time job. This has been an increasing concern for many Maltese fishermen and is the result of increasing difficulties that fishers have been facing, discouraging their future fishing prospects. Even though unemployment is a problem found across most Maltese and EU workforce sectors, self-employed fishers could sustain themselves and their families in humble ways. However, with the increasing difficulties that fishers are facing, youths in fisher communities are demoralized to make a living from fishing, even though all the necessary gear and training would be available through their close relationships and exposure to fishermen's families or fishing community.

The low self-esteem felt by most fishermen is often caused by the top-down management and control system increasingly being applied in Malta. This situation is seeing a gradual loss of tradition, experience, and pride in fishing as a noble way of earning a living while respecting 


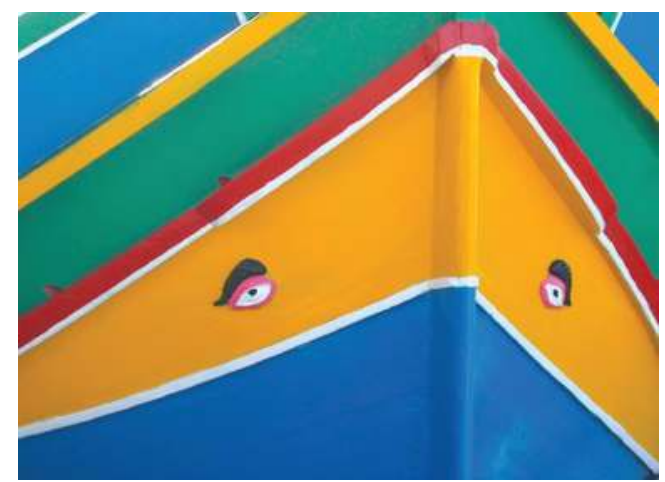

Figure 1. Photo of front of Maltese artisanal boat with the eyes of Osiris thought to protect the fishermen out at sea.

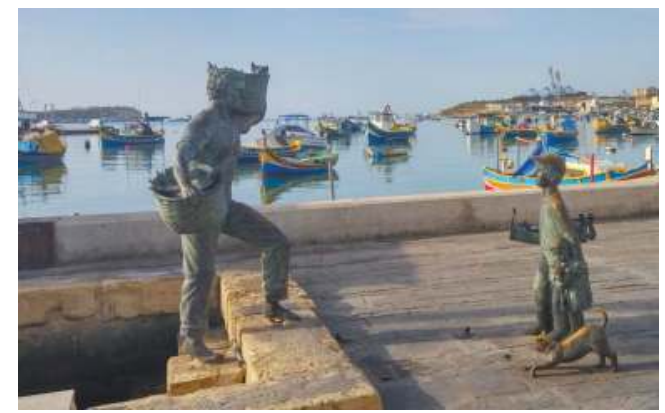

Figure 2. Photo of bronze sculpture at Marsaxlokk fishing village (Malta) with artisanal fishing boats in the background. Promoting the fishing tradition and heritage of this village.

that same sea, which provides for the whole family, generation after generation. This intimate relationship with the sea as provider of goods in the long-term is being lost with the loss of fishing traditions, communities and villages.

With the change in SSF management and control, more fishers see fishing as an activity to undertake simply for temporary or periodic pleasure and not as a full-time dedicated endeavor that needs to be safeguarded for many generations to come. This is clear from the increasing number and larger proportion of leisure fishing boats when compared to the full-time small-scale fishing boats registered in Malta. The self-controlling mechanism that was present among artisanal and experienced fishers is being transformed into a short-term profit-making or leisure activity, which is heavily controlled by local fisheries authorities. The latter pass on legislations and policies in line with controlling mechanisms designed for much larger-scale fisher communities of the EU, which may not be experiencing the difficulties and risks felt by the much smaller fisher community in the Maltese Islands. Real dialog and considerations of the serious implications of the adoption of EU regulations, controls and enforcement of regulations with Maltese fishers is an unresolved problem, which has emerged during ongoing research by the authors. 
Urgent and in depth assessment of the impacts of currently adopted and prospective regulations is needed. Such assessment has to look into the effectiveness and problems of fisheries regulations on the welfare of both local marine biodiversity and local fishers. For this reason, the CBRG-UoM, has been sustaining long-term research on artisanal fishing activities in Malta since 1998, identifying the need for greater collaboration between fishers, fishing authorities and independent researchers that would bring about the necessary scientific information on fishing activities, conservation needs of marine resources and knowledge gaps to be clearly assessed. Such independent reviews are necessary to reduce the exclusive topdown control with poor consideration of the impacts of inaccurate or incomplete information being considered at both local and EU levels when planning for management improvements in the fisheries sector. Both fishermen's skills and nature's ways of adapting to a changing marine environment need to be investigated to assess the resilience of both fishermen and biodiversity in the region. In order to consider such interlinked relationships between SSF and marine species conservation two aspects linking fisheries and endangered native biodiversity are presented here: 1) the Maltese SSF landings of sharks and rays (elasmobranches) species with a case study on how artisanal small-scale fishing of one shark species proves to be sustainable when investigated in detail and 2) Alien (non-native) reef species increasingly discovered in Maltese waters are identified through genetic DNA barcoding and found to be species that may compete or prey on native reef fish, such as groupers and related Serranidae species. The latter already suffering from over exploitation and environmental degradation.

\section{Protecting vulnerable elasmobranch species: targeting marine biodiversity conservation}

In the Mediterranean, elasmobranches account for less than $1.5 \%$ of the total fish landings in the area [4], therefore their economic importance is much lower than that of teleosts, nonetheless they have an important socio-economic role in Mediterranean fisheries [2, 22, 23].

On a global scale, elasmobranch landing records have shown drastic reduction for several species, with global negative population trends. This has led to a growing list of elasmobranch species within the high risk conservation categories of the IUCN Red List, with overfishing being the main threat for the declining stocks [24-31].

At a Mediterranean level, the total number of elasmobranch species inhabiting the region adds up to around $80[26,27,30,32,33]$. A number of these species have a worse conservation status within the Mediterranean, when compared to their global conservation status since this region is highly populated with evergrowing coastal communities, fishing activities and maritime services, leading to increased pressure on the existing elasmobranch populations, their prey and habitats [27, 28, 30, 31, 34]. In the Mediterranean Sea, higher risk is further exacerbated by limited migration between populations within and outside the region [31, 35].

Despite the increased vulnerability, there are no official records of chondrichthyes that have been totally extirpated from the Mediterranean [27, 28, 31] although there has been a significant decline in their landings both in terms of biomass and numbers, and it is known that some species have disappeared from certain areas [26, 28, 36, 37]. The European landing 
records for Mediterranean chondrichthyes recorded a decline of around 60\% between 1994 and 2004, namely due to declining stocks [4, 27, 30, 31]. These factors together with incomplete knowledge about their fisheries, trophic linkages and species specific life-history data make it really difficult to pinpoint the first warning signs of stock decline, making these top predators more vulnerable to anthropogenic activities, which impose both direct and indirect pressures to their survival. However, these threats, not only affect the survival of the species, but also the livelihood of small-scale fishermen who for decades have earned their living from these marine resources.

Traditionally, elasmobranch fisheries in Malta are an integral part of the annual landings, with few local fishermen targeting elasmobranches as primary or secondary target species, while several others capture them as by-catch of various fishing activities [2]. In Malta, these fisheries have always been limited to small-scale fishermen, with most of their operations being carried out within the 25 NM FMZ. However long term direct and indirect pressures have led to drastic reductions and disappearance in the landings of certain species, mostly pelagic sharks such as hammerhead sharks (Sphyrna spp.) and porbeagle (Lamna nasus) [26], which could have declined not only due to direct exploitation but due to the exploitation of their pelagic prey [26]. Moreover, the life-history of these pelagic species covers wide home ranges and thus the declining stocks are not only influenced by local activities but also by international large-scale fishing activities carried out in neighboring fishing grounds [2]. On the other hand, other elasmobranch species that attract little international interest, are regularly caught, and seem to be more resilient to current anthropogenic pressures. One such example is the small local fishery related to the bluntnose sixgill shark, Hexanchus griseus.

Fishing grounds along the South to South-West of Malta are rich in deep submarine canyons with very steep slopes and drop-offs [38]. Such bathymetric features attract a number of species [39-41] and are able to provide the right ecosystems to sustain large top predators including deep-water elasmobranches such as $H$. griseus $[38,42,43]$. The occurrence of these geographical formations within a short distance from major Maltese fishing ports have led few local artisanal fishermen to specifically target $H$. griseus along drop-offs off the Maltese coast both within and outside the FMZ. This fishery is at least a number of decades old [26], with an annual landing record ranging between 1256 (in 1986) and $8529 \mathrm{~kg}$ (in 2002), with an average annual record of $4277 \mathrm{~kg}( \pm 2033 \mathrm{~kg})$ (Malta Fisheries Landing Data 1986-2016) (Figure 3). Nonetheless, the apparent lack of interest in the species by other Mediterranean countries does not exclude that $H$. griseus is not being regularly exploited as by-catch, possibly unreported or lumped in other shark categories due to its low economic importance. On a global scale, species-specific landing records for H. griseus are scarce [4].

The Maltese landings of $H$. griseus are characterized by seasonal changes, as most of the catches are noted during the first quarter of the year with $49.5 \%$ being caught between February and March [44, 45], a time when due to religious traditions several Maltese people tend to prefer consuming fish rather than meat. During this period, the fishing effort targeting deepwater fisheries increases drastically as fishermen having vessels $>12 \mathrm{~m}$ exploit waters outside the FMZ, with most of the latter employing a small number of fishermen on-board and use demersal bottom long-lines to harvest $H$. griseus. However, these months are characterized by rough seas and thus limits the operations and the fishing effort that these fishermen can dedicate to deep-sea fishing. 


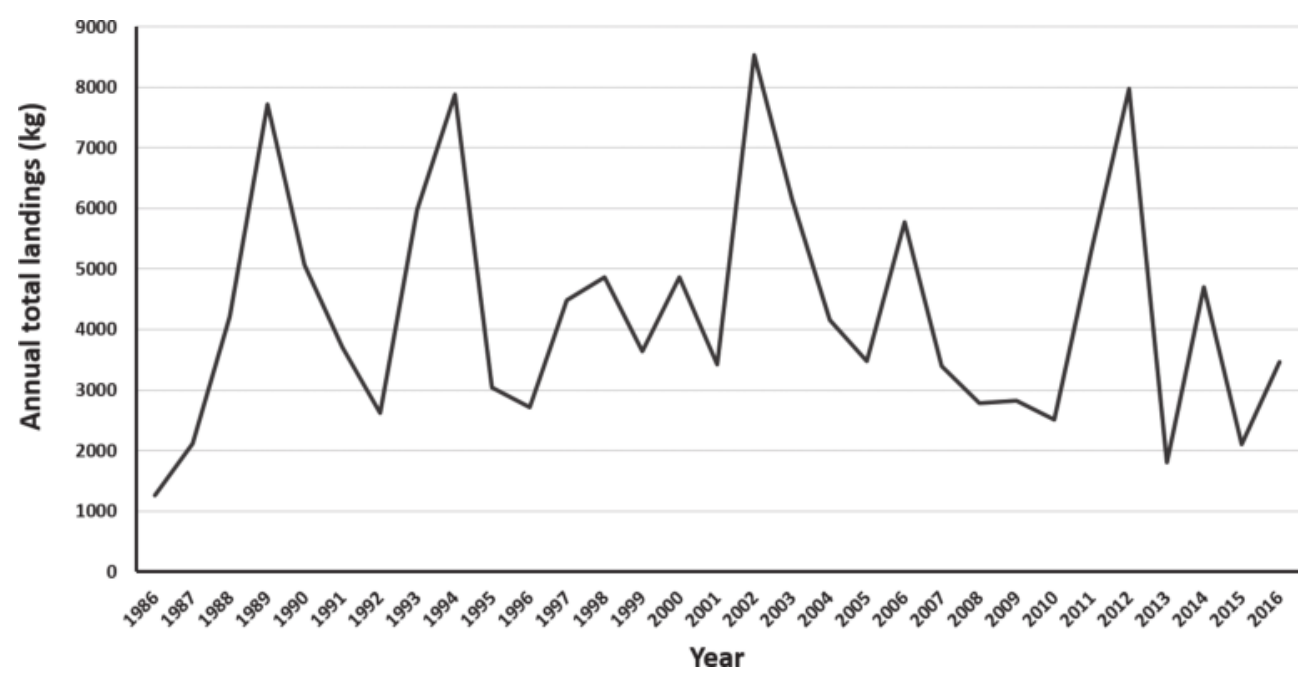

Figure 3. The annual landings (kg) of Hexanchus griseus in Malta for the years 1986 till 2016 (Department of Fisheries, National Statistics).

Most of the Maltese fishermen change their fishing strategies depending on the open fishing season, migratory patterns of the species and the local market's needs. Thus as they alter their operations, the fishing effort for demersal deep-water species lowers to target more economically important species such as Thunnus thynnus, Xiphias gladius and Coryphaena hippurus. Nonetheless, some $H$. griseus landings persist throughout the year due to by-catch from trawling activities and by a very few individual fishermen with boats $<12 \mathrm{~m}$ who fish for demersal deep-water species all year round. The latter use bottom long-lines and alter between different fishing grounds targeting different species, including H. griseus.

Although currently there is no direct local or EU legislation limiting landings of $H$. griseus, both Maltese legislation and the EU council regulations [14, 20] identified H. griseus as a species that requires monitoring and precautionary management actions to protect the species.

In this scenario, it has to be noted that any protective measures have to consider that in Malta, $H$. griseus is a socio-economically important species to a small number of local small-scale fishermen who have sustainably harvested this resource for decades. Its presence is important to their livelihood especially during the winter months when this shark is caught as an alternative to other commercially important species, while throughout the year it provides a small sustained income to a handful of individual fishermen with small fishing vessels $(<12 \mathrm{~m})$. Moreover, given that local fishermen (except trawlers) tend to diversify fishing activities, then $H$. griseus provides another fishing alternative, sustaining a balance between other commercially important species. The current small-scale fishery of this species has benefitted from scientifically based knowledge, which guarantees the survival of the species through an early warning sign of stock depletion, while ensuring the sustainability of its fishery and the livelihood of the fishermen involved [35, 44-46]. 


\section{Changing marine biodiversity through increasing presence of alien species}

Research methods used to study species caught by artisanal fishermen include interview and field surveys, which have allowed the discovery of various concerns, affecting SSF and marine biodiversity in Maltese waters.

Apart from the problems faced by SSF fishermen affected by the limited space available for fishing due to the designations for marine protected areas, aquaculture, tuna penning, swimming, bunkering zones, wrecks, SCUBA diving areas, Freeport and Port activities, there is the increasing concern of marine environmental changes affecting marine life on reefs and coastal waters in particular. Changes due to marine pollution, climate change and anthropogenic introduction of alien species. These changes have also been considered to have affected periodical blooming of gelatinous species in various Mediterranean regions, including Maltese waters, which have also procured episodes of discomfort for some SSF [47].

Alien species presence increasingly observed in the Mediterranean Sea is reported to have been caused by various factors [34, 48]. In turn the increasing number of alien species that become invasive pose serious impacts to fishermen that are faced with strange and unknown species in their catch, some of which are poisonous. Examples of these include the silver-cheeked toadfish (Lagocephalus sceleratus) which has expanded its presence in the Mediterranean Sea since its first record from Gökova Bay, Turkey, in 2004 [49]. The lionfish (Pterois miles) invasion has also been reported in the Mediterranean Sea [50], after its initial presence was reported in 1991 off Israel [51]. However, as various species entering the Mediterranean become invasive even before detailed analyses on these alien species are undertaken, little is really known about their adaptations and genetics after they spread their distribution into the Mediterranean [52]. For this reason, genetic tools were also used to study alien species

\begin{tabular}{|c|c|c|c|c|}
\hline Species & Habitat preference $^{1}$ & Depth range $^{1}$ & Status $^{2}$ & Reference \\
\hline Stegastes variabilis & Reef-associated & $0-30 \mathrm{~m}$ & Casual & [53] \\
\hline Lutjanus fulviflamma & Reef-associated & $3-35 \mathrm{~m}$ & Casual & {$[54]$} \\
\hline Abudefduf hoefleri & Reef-associated & - & Established & [55] \\
\hline Abudefduf vaigiensis & Reef-associated & $1-15 \mathrm{~m}$ & Established & {$[56]$} \\
\hline Kyphosus vaigiensis & Reef-associated & $0-40 \mathrm{~m}$ & Established & {$[57]$} \\
\hline Cephalopholis nigri & Demersal & Down to $100 \mathrm{~m}$ & Casual & {$[58]$} \\
\hline Cephalopholis taeniops & Demersal & $20-200 \mathrm{~m}$ & Established & [58] \\
\hline Holocentrus adscensionis & Reef-associated & $0-180 \mathrm{~m}$ & Casual & [59] \\
\hline Acanthurus monroviae & Demersal & 5-200 m & Established & {$[60]$} \\
\hline
\end{tabular}

${ }^{1}$ Www.fishbase.org.

${ }^{2}$ Status based on criteria by CIESM (www.ciesm.org/atlas/appendix1.html).

Table 1. A list of the alien fish species recorded in Maltese waters whose identity was confirmed through morphological and genetic analyses. 
found in Maltese waters by using DNA barcoding (Table 1) as a first step toward accurate identification of species followed by other molecular markers once several specimens were sampled from different parts of their distribution, as has been carried out with native species.

Alien species found in Maltese waters and constituting first records in the Mediterranean have been studied and monitored in these waters. Such studies that also involve fishermen's cooperation [53-60] furnish useful early warning signals for timely management of bioinvasions.

Among the various alien reef species caught in shallow Maltese waters and identified genetically as well as morphologically one finds: the Cocoa damselfish, Stegastes variabilis; the Dory snapper, Lutjanus fulviflamma; the African sergeant, Abudefduf hoefleri; the Indopacific sergeant, Abudefduf vaigiensis (Quoy and Gaimard, 1825) [56]; the Lowfin chub, Kyphosus vaigiensis (Quoy and Gaimard, 1825) [57]); the African Hind, Cephalopholis taeniops and the Niger Hind, Cephalopholis nigri; the Squirrelfish, Holocentrus adscensionis (Osbeck, 1765) [59]; and the Monrovia doctorfish, Acanthurus monroviae (Steindachner, 1876) [60]). Figures 4 and 5 show some of the alien species caught in Maltese waters. Table 1 shows the habitat preference of these species and the current status of these species in Maltese waters. Through ongoing research and monitoring it was possible to confirm species establishment while other potentially dangerous and invasive species such as the pufferfish and lionfish species were also spotted [61] posing particular cumulative impacts on fisheries and native reef species. The diversity of invasive species may produce diverse impacts that still need to be understood $[8,9]$.

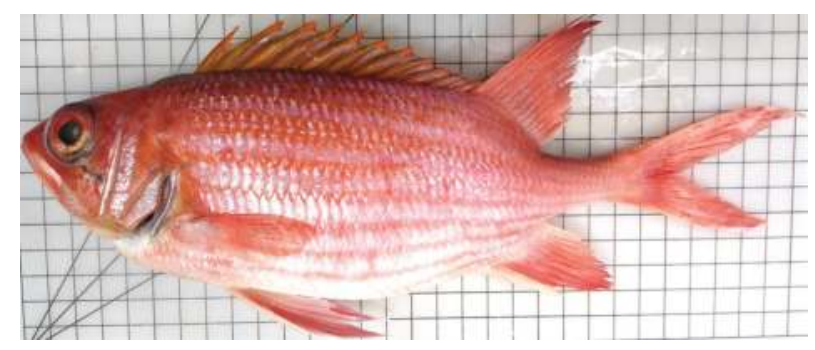

Figure 4. Photo of the Squirrel fish, Holocentrus adscensionis (Osbeck, 1765) (Beryciformes: Holocentridae), first record of its presence in the Mediterranean Sea [59]. This species is a subtropical reef-associated fish native to the Atlantic Ocean and may therefore compete with native Mediterranean reef species.

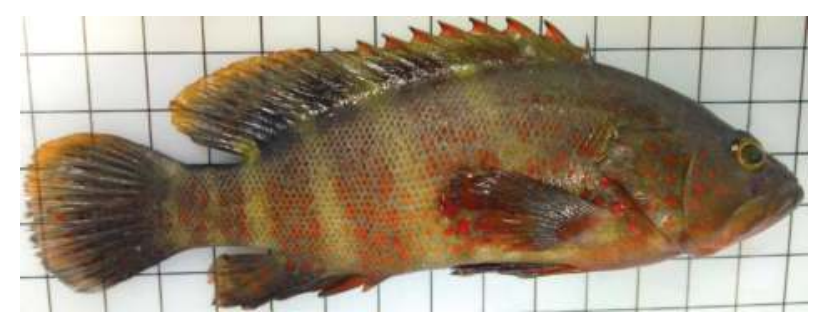

Figure 5. Photo of the alien Niger Hind, Cephalopholis nigri (Perciformes: Serranidae), from Maltese coastal water [58]. 
FAO data for the GFCM area indicates that in 2014 at least $5.7 \%$ of the marine fish landings were classified as unidentified, while several others, including some species of groupers, are classified down to high taxonomic levels such as Epinephelus spp. [4]. Direct exploitation has been the main cause leading to the inclusion of Epinephelus marginatus as an endangered species within the IUCN Red List of Threatened Species both at global [62] and at Mediterranean level [62] due to serious declines in its population. However, environmental changes in the marine habitats due to climate change, anthropogenic activities and increasing presence of alien species [34, 48, 53-60] are posing additional threats to the Serranidae species in the central Mediterranean Sea. Therefore, to ensure effective conservation measures, the genetic identity and phylogenetics of the species around the Maltese Islands were studied to compare these with similar species found elsewhere within and outside the Mediterranean region. Accurate genetic identification through the analyses of multiple genes can be used as molecular tools to assess the genetic identity and phylogenetic relationships between species, while subtle genetic differences found within each species can provide preliminary understanding of its phylogeographic distribution, thus identifying any distinct stocks or limited gene flow.

Impacts of reef alien species, which may compete or prey upon local reef species, need urgent consideration and further ongoing research. The latter is necessary for both the conservation of vulnerable species and the safeguard of fish communities from environmental impacts that affect SSF as well. The results of these anthropogenic and natural studies are integrated to provide an important holistic view of how the Mediterranean region is changing in these sectors.

\section{Concluding discussion}

Small-scale artisanal fisheries are in fast decline in the Maltese Islands, which reflects a symptom around the Mediterranean where both policies and environmental change are having a heavy toll on these ancient maritime traditions. However, recreational fishing vessels that are not monitored closely are in rapid increase. According to the key elements of the Strategic Plan 2011-2020, including Aichi Biodiversity Targets, Strategic Goal A-Target 1 states that by 2020, at the latest, people are aware of the values of biodiversity and the steps they can take to conserve and use it sustainably. Traditional small-scale fishers are the first to invoke conservation and sustainable use but need to be assisted in their adaptation to the many changes affecting their futures from climate change to closed seasons to increasingly importation of fish foods from abroad. Target 2 states that by 2020, at the latest, biodiversity values have been integrated into national and local development and poverty reduction strategies and planning processes are being incorporated into national accounting, as appropriate and reporting systems. Will this consider the poverty that is increasing among small-scale fishermen?

Strategic Goal B-Target 6 states that by 2020, all fish and invertebrate stocks and aquatic plants are managed and harvested sustainably, legally and applying ecosystem based approaches, so that overfishing is avoided, recovery plans and measures are in place for all depleted species, fisheries have no significant adverse impacts on threatened species and vulnerable ecosystems and the impacts of fisheries on stocks, species and ecosystems are within safe ecological limits. This relevant and ambitious target demands close collaboration between fishers, researchers and managers in order to find 
effective ways forward without ignoring the socio-economic consequences to small-scale fishermen [63]. Just as in developing countries and island states, small-scale fisheries are increasingly considered as vulnerable and recognized as deserving greater attention and closer innovative interventions in collaboration with the fishers themselves, Maltese fishers need to find greater comprehension and assistance so as to facilitate their sustainability at both socioeconomic and environmental levels. Regulations need to be useful to both the environment and fishers, allowing equitable and sustainable sharing of the resources rather than allowing for exclusivity and monopoly of few commercial fishers. Regulations must be economically and environmentally viable, taking into account the impacts of climate change. At the same time, full-time fishers need to be allowed to become more active in research and monitoring. Inclusion rather than exclusion of stakeholders in the assessment and decision-making process would strengthen the efficacy of any long-term management plan [64]. Mediterranean fish populations tend to support multi-species and seasonal multi-gear SSF, where regional governance systems also affect fisheries sustainability levels. Management in such conditions requires an understanding of the nature of each fishery as a complex socio-ecological system needing to find effective and lasting solutions for the communities involved [65]. While smallscale fishing can be harmful when its aggregated impact on the stocks is significant, spatial and seasonal planning of shared SSF activities should avoid such impacts. There are also cases where small and large-scale fleets targeting the same stocks are not regulated through different mechanisms in reflection of the different levels of impact. A differentiated management design targeting the ecological sustainability of these shared stocks is essential [13]. At the same time, the environmental changes, including the increasing number of alien and invasive species, demand effective involvement of fishermen as valuable monitors and practitioners of sustainable fisheries in order to safeguard Mediterranean biodiversity and heritage.

\section{Acknowledgements}

Thanks are due to Maltese artisanal fishermen who have shared their experiences and concerns for their futures with us during our interviews and research. Mr. Clayton Buttigieg, Manager Fisheries \& Aquaculture Licenses, Department of Fisheries and AquacultureFishing Vessel Register, Ministry for Sustainable development, the environment and climate change for providing relevant information for 2015. Statistics officers at the Department of Fisheries and the National Statistics Office Malta for providing additional landings statistics.

The REACH HIGH Scholars Programme-Post Doctoral Grants, part-financed by the European Union, Operational Programme II - Cohesion Policy 2014 - 2020 "Investing in human capital to create more opportunities and promote the well-being of society" - European Social Fund.

\section{Author details}

Adriana Vella* and Noel Vella

*Address all correspondence to: adriana.vella@um.edu.mt

Conservation Biology Research Group, Department of Biology, University of Malta, Malta 


\section{References}

[1] FAO. The State of World Fisheries and Aquaculture: Opportunities and Challenges. Rome: FAO; 2014. p. 223

[2] Vella A. Sustainable Fisheries in the Mediterranean. Barcelona, Spain: Regional Activity Centre for Cleaner Production (CP/RAC) Mediterranean Action Plan; 2009. $142 \mathrm{p}$

[3] Vasilakopoulos P, Maravelias CD, Tserpes G. The alarming decline of Mediterranean fish stocks. Current Biology. 2014;24:1643-1648

[4] FAO. Fisheries and Aquaculture topics. Online Query Panels. Topics Fact Sheets. Fisheries Global Information System (FIGIS). 2017. Available from: http://www.fao.org/ fishery/statistics/global-commodities-production/query/en [Accessed: 02-06-2017]

[5] Tsagarakis K, Palialexis A, Vassilopoulou V. Mediterranean fishery discards: Review of the existing knowledge. ICES Journal of Marine Science. 2014;71(5):1219-1234

[6] Zaiko A, Lehtiniemi M, Narščius A, Olenin S. Assessment of bioinvasion impacts on a regional scale: A comparative approach. Biological Invasions. 2011;13;1739-1765

[7] Zenetos A, Gofas S, Morri C. Alien species in the Mediterranean Sea by 2012. A contribution to the application of European Union's marine strategy framework directive (MSFD). Part 2. Introduction trends and pathways. Mediterranean Marine Science. 2012;13:328-352

[8] Katsanevakis S, Wallentinus I, Zenetos A, Leppäkoski E, Çinar ME, Oztürk B, Grabowski M, Golani D., Cardoso AC. Impacts of marine invasive alien species on ecosystem services and biodiversity: A pan-European review. Aquatic Invasions. 2014;9:391-423

[9] Katsanevakis S, Coll M, Piroddi C, Steenbeek J, Ben Rais Lasram F, Zenetos A, Cardoso AC. Invading the Mediterranean Sea: Biodiversity patterns shaped by human activities. Frontiers in Marine Science. 2014;1:32

[10] Rouillard J, Lago M, Abhold K, Roeschel L, Kafyeke T, Klimmek H, Mattheiß V. Aquacross: Synergies and differences between biodiversity, nature, water and marine environment EU policies. October 2016. p. 158. Available from: http://ecologic.eu/sites/ files/publication/2016/2803-d2-1-synergies-and-differences-between-eu-policies-withannexes-03112016.pdf

[11] Bruyninckx H. Effective policies are based on a robust knowledge base and solid science. The editorial published in the EEA Newsletter 01/2017, March 2017. Available from: http://www.eea.europa.eu/articles/effective-policies-are-based-on

[12] Piante C, Ody D. Blue Growth in the Mediterranean Sea: The Challenge of Good Environmental Status. MedTrends Project. France: WWF-France; 2015. 192 p

[13] EU Com. Green Paper: Reform of the Common Fisheries Policy, Brussels, 22.4.2009 $\operatorname{COM}(2009) 163$ final. 2009. $27 \mathrm{p}$

[14] EUR-Lex. EUR-Lex: Access to European Union Law. 2017. Available from: http://eur-lex. europa.eu/en/index.htm [Accessed: 02-06-2017] 
[15] Fisheries Control Directorate. Fisheries Management Plan. 2013.79 p. Available from: https:/ stecf.jrc.ec.europa.eu/documents/43805/595618/Maltas+Fisheries+Management+Plan++Trawler+and+Lamapra.pdf

[16] STECF. Scientific, Technical and Economic Committee for Fisheries: The 2012 Assessment of Mediterranean Sea Stocks part II (STECF 13-05). Publications Office of the European Union, Luxembourg, EUR 25309 EN, JRC 81592. 2013. 618 p

[17] STECF. Scientific, Technical and Economic Committee for Fisheries-The 2014 Annual Economic Report on the EU Fishing Fleet (STECF-13-15). 2014. Publications Office of the European Union, Luxembourg, EUR 26258 EN, JRC 84745. 2014. 302 p

[18] STECF. Scientific, Technical and Economic Committee for Fisheries-The 2014 Annual Economic Report on the EU Fishing Fleet (STECF-14-16). Publications Office of the European Union, Luxembourg, EUR 26901 EN, JRC 92507. 2014. 363 p

[19] STECF. Scientific, Technical and Economic Committee for Fisheries: Standardization Procedures for Data Preparation, Stock Assessment Methods and Estimate of MSY Reference Points for Mediterranean Stocks (STECF-15-11). Publications Office of the European Union, Luxembourg, EUR 27408 EN, JRC 97017, 2015. 104 p

[20] Maltese Legislation. Laws of Malta [online] (MJLC search). 2017. Available from: http:// justiceservices.gov.mt/LegalServicesSearch.aspx?type=lom\&pageid=29 [Accessed: 02-06-2017]

[21] FAO. Organisation des Nations Unies pour l'alimentation et l'agriculture. The republic of Malta. 2005. Available from: http://www.fao.org/fi/oldsite/FCP/en/MLT/profile.htm [Accessed: January, 2017]

[22] Vannuccini S. Shark Utilization, Marketing and Trade. Rome: FAO; 1999. 470 p

[23] Fisheries Control Directorate. Fisheries Operational Programme for Malta 2007-2013. Malta. 2008. 89 p. Available from: https:/ec.europa.eu/fisheries/sites/fisheries/files/docs/ body/malta_en.pdf [Accessed: 6-02-2017]

[24] Stevens J, Bonfil R, Dulvy N, Walker PA. The effects of fishing on sharks, rays, and chimaeras (Chondrichthyans), and the implications for marine ecosystems. ICES Journal of Marine Science. 2000;57(3):476-494

[25] Reynolds JD, Dulvy N, Roberts CM. Exploitation and other threats to fish conservation. In: Hart P, Reynolds J, editors. Handbook of Fish Biology and Fisheries. Vol. 2. Oxford: Blackwell Publishing Ltd; 2002. pp. 319-341

[26] Dalli J. Elasmobranches around the Maltese Islands: Field and Fisheries Study for Conservation [M.Sc. Thesis]. Malta: University of Malta; 2003

[27] Cavanagh RD, Gibson C. Overview of the Conservation Status of Cartilaginous Fishes (Chondrichthyans) in the Mediterranean Sea. Gland, Switzerland and Malaga, Spain: IUCN; 2007. $442 \mathrm{p}$

[28] Ferretti F, Myers RA, Serena F, Lotze HK. Loss of large predatory sharks from the Mediterranean Sea. Conservation Biology. 2008;22(4):952-964 
[29] Camhi MD, Valenti SV, Fordham SV, Fowler SL, Gibson C. The Conservation Status of Pelagic Sharks and Rays: Report of the IUCN Shark Specialist Group, Pelagic Shark Red List Workshop. Commission Shark. Newbury, UK: IUCN Species Survival Commission Shark Specialist Group; 2009. 78 p

[30] Abdul Malak D, Livingstone SR, Pollard D, Polidoro BA, Cuttelod A, Bariche M, Bilecenoglu M, Carpenter KE, Collette BB, Francour P, Goren M, Hichem Kara M, Massutí E, Papaconstantinou C, Tunesi L. Overview of the Conservation Status of the Marine Fishes of the Mediterranean Sea. Gland, Switzerland and Malaga, Spain: IUCN; 2011. 61 p

[31] IUCN. IUCN Red List of Threatened Species. 2017. Available from: http://www.iucnredlist.org/ [Accessed: 02-06-2017]

[32] Serena F. Field Identification Guide to the Sharks and Rays of the Mediterranean and Black Sea. Species Identification Guide for Fishery Purposes. Rome: FAO; 2005. 97 p

[33] Bariche M. Field Identification Guide to the Living Marine Resources of the Eastern and Southern Mediterranean. Species Identification Guide for Fishery Purposes. Rome: FAO; 2012. $610 \mathrm{p}$

[34] Coll M, Piroddi C, Steenbeek J, Kaschner K, Ben Rais Lasram F, Aguzzi J, Voultsiadou E. The biodiversity of the Mediterranean Sea: Estimates, patterns, and threats. PLoS One 2010;5(8):e11842

[35] Vella N, Vella A. Phylogeography of Hexanchus griseus, inferred from the mtDNA control region. Rapport Commission Internationale pour l'Exploration Scientifique de la Méditerranée. 2013;40:707

[36] Maynou F, Sbrana M, Sartor P, Maravelias C, Kavadas S, Damalas D, Cartes JE, Osio G. Estimating trends of population decline in long-lived marine species in the Mediterranean Sea based on fishers' perceptions. PLoS One. 2011;6(7):e21818

[37] Tremblay-Boyer L, Gascuel D, Watson R, Christensen V, Pauly D. Modelling the effects of fishing on the biomass of the world's oceans from 1950 to 2006. Marine Ecology Progress Series. 2011;442:169-185

[38] Vella A, Vella J. Central-southern Mediterranean submarine canyons and steep slopes: Role played in the distribution of cetaceans, bluefin tunas, and elasmobranchs. In: Würtz M, editor. Mediterranean Submarine Canyons: Ecology and Governance. Gland, Switzerland and Malaga, Spain: IUCN; 2012. pp. 73-88

[39] Flexas MM, Boyer DL, Espino M, Puigdefàbregas J, Rubio A, Company JB. Circulation over a submarine canyon in the NW Mediterranean. Journal of Geophysical Research. 2008;113(C12):1978-2012

[40] Allen SE, Durrieu de Madron X. A review of the role of submarine canyons in deepocean exchange with the shelf. Ocean Science Discussions. 2009;6(2):1369-1406

[41] Würsig B. Submarine canyons and their role in the Mediterranean ecosystem. In: Würsig B, editor. Mediterranean Submarine Canyons: Ecology and Governance. Gland, Switzerland and Malaga, Spain: IUCN; 2012. pp. 11-27 
[42] Öztürk B, Topçu E, Topaloglu B. The submarine canyons of the Rhodes basin and the Mediterranean coast of Turkey. In: Würsig B, editor. Mediterranean Submarine Canyons: Ecology and Governance. Gland, Switzerland and Malaga, Spain: IUCN; 2012. pp. 65-71

[43] Watremez P. Canyon heads in the French Mediterranean overview of results from the MEDSEACAN and CORSEACAN campaigns (2008-2010). In: Würsig B, editor. Mediterranean Submarine Canyons: Ecology and Governance. Gland, Switzerland and Malaga, Spain: IUCN; 2012. pp. 104-112

[44] Vella N, Vella A. A preliminary study of the bluntnose sixgill shark, Hexanchus griseus, in the Central Mediterranean region, around the Maltese islands. Rapport Commission Internationale pour l'Exploration Scientifique de la Méditerranée. 2010;39:695

[45] Vella N, Vella A. Records on the Landings of the Bluntnose Sixgill Shark, Hexanchus griseus, in Malta. Report of the 11th Session of the Sub-committee on Marine Environment and Ecosystems (SCMEE)-Scientific Advisory Committee of the GFCM. FAO: Rome; 2010. GFCM:SAC13/2011/Inf.5

[46] Vella N. Conservation Genetics of the Bluntnose Sixgill Shark, Hexanchus griseus, in the Mediterranean [Ph.D. Thesis]. Malta: University of Malta; 2013. p. 246

[47] Vella A, Vella N. Jellyfish blooming in maltese waters and its socio-economic interactions (pp. 163-188) Chapter 7. In: Mariottini GL, editor. Jellyfish: Ecology, Distribution Patterns and Human Interactions: Fish, Fishing and Fisheries Series. USA: Nova Science Publishers, Inc.; 2017. p. 352

[48] Occhipinti-Ambrogi A, Galil B. Marine alien species as an aspect of global change. Advances in Oceanography and Limnology. 2010;1:199-218

[49] Filiz H, Er M. Akdeniz'in Yeni Misafiri (New guests in the Mediterranean Sea). Deniz Magazin Dergisi. 2004;3(68):52-54

[50] Kletou D, Hall-Spencer JM, Kleitou P. A lionfish (Pterois miles) invasion has begun in the Mediterranean Sea. Marine Biodiversity Records. 2016;9:e46

[51] Golani D, Sonin O. New records of the Red Sea fishes, Pterois miles (Scorpaenidae) and Pteragogus pelycus (Labridae) from the eastern Mediterranean Sea. Japanese Journal of Ichthyology. 1992;39(2):167-169

[52] Bernardi G, Golani D, Azzurro E. The genetics of Lessepian bioinvasions. In: Golani D, Appelbaum-Golani B, editors. Fish Invasions of the Mediterranean Sea: Change and Renewal. Sofia, Moscow: Pensoft Publishes; 2010. pp. 71-84

[53] Vella A, Agius Darmanin S, Vella N. Morphological and genetic barcoding study confirming the first Stegastes variabilis (Castelnau, 1855) report in the Mediterranean Sea. Mediterranean Marine Science. 2015;16(3):609-612

[54] Vella A, Vella N, Agius DS. First record of Lutjanus fulviflamma (Osteichthyes: Lutjanidae) in the Mediterranean Sea. Journal of the Black Sea/Mediterranean Environment. 2015;21(3):307-315 
[55] Vella A, Vella N, Agius DS. The first record of the African sergeant, Abudefduf hoefleri (Perciformes: Pomacentridae), in the Mediterranean Sea. Marine Biodiversity Records. 2016;9(1):1-5

[56] Vella A, Agius Darmanin S, Vella N. The first records of Indo-Pacific sergeant Abudefduf vaigiensis (Quoy \& Gaimard, 1825) and further notes on the occurrence of sergeant major A. saxatilis (Linnaeus, 1758) in Malta: Expanding populations of an invasive genus in the Mediterranean Sea. Journal of the Black Sea/Mediterranean Environment. 2016;22(1):1-15

[57] Vella N, Vella A, Agius Darmanin S. The first record of the lowfin chub Kyphosus vaigiensis (Quoy \& Gaimard, 1825) from Malta. Journal of the Black Sea/Mediterranean Environment. 2016;22(2):175-181

[58] Vella N, Vella A, Agius DS. Morphological and genetic analyses of the first record of the Niger hind, Cephalopholis nigri (Perciformes: Serranidae), in the Mediterranean Sea and of the African hind, Cephalopholis taeniops, in Malta. Marine Biodiversity Records. 2016;9:e99

[59] Vella A, Vella N, Agius Darmanin S. The first record of the longjaw squirrelfish, Holocentrus adscensionis (Osbeck, 1765) (Holocentriformes: Holocentridae), in the Mediterranean Sea. Natural and Engineering Sciences. 2016;1(3):78-85

[60] Agius Darmanin S, Vella N, Vella A. Genetic, morphometric and meristic analyses of first Monrovia Surgeonfish Acanthurus monroviae (Steindachner, 1876) specimens recorded in Maltese waters (Central Mediterranean). Cybium. 2016;40(4):338-340

[61] Vella A. Ongoing Research Finds New Alien Species in Maltese Waters, University of Malta newspoint. 2016. Available from: https://www.um.edu.mt/newspoint/news/features/2016/07/ ongoingresearchfindsnewalienspeciesinmaltesewaters and http://www. maritimedirectory.com.mt/newsread.asp?l=e\&ID=3962 [Accessed: 02-06-2017]

[62] Cornish A, Harmelin-Vivien M. Epinephelus marginatus. The IUCN Red List of Threatened Species. 2011:e.T7859A12856576. http://www.iucnredlist.org/details/7859/0 [Accessed: 01-24-2017]

[63] CBD. Convention on Biological Diversity: Technical Rationale. 2016. Available from: https://www.cbd.int/sp/targets/rationale/default.shtml [Accessed: 02-06-2017]

[64] Béné C, Devereux S, Roelen K. Social protection and sustainable natural resource management: Initial findings and good practices from small-scale fisheries. FAO Fisheries and Aquaculture Circular No. 1106. Rome: FAO; 2015. p. 61

[65] Smith ADM, Garcia SM. Fishery management: Contrasts in the Mediterranean and the Atlantic. Current Biology. 2014;4(17):R810-R812 
